\title{
Functional Interaction between T2R Taste Receptors and G-Protein $\alpha$ Subunits Expressed in Taste Receptor Cells
}

\author{
Takashi Ueda, ${ }^{1}$ Shinya Ugawa, ${ }^{1}$ Hisao Yamamura, ${ }^{1,2}$ Yuji Imaizumi, ${ }^{2}$ and Shoichi Shimada, ${ }^{1}$ \\ ${ }^{1}$ Department of Molecular Morphology, Graduate School of Medical Sciences, Nagoya City University, and ${ }^{2}$ Department of Molecular and Cellular \\ Pharmacology, Graduate School of Pharmaceutical Sciences, Nagoya City University, Nagoya 467-8601, Japan
}

\begin{abstract}
Bitter taste perception is a conserved chemical sense against the ingestion of poisonous substances in mammals. A multigene family of G-protein-coupled receptors, T2R (so-called TAS2R or TRB) receptors and a G-protein $\alpha$ subunit (G $\alpha$ ), gustducin, are believed to be key molecules for its perception, but little is known about the molecular basis for its interaction. Here, we use a heterologous expression system to determine a specific domain of gustducin necessary for T2R coupling. Two chimeric G $\alpha 16$ proteins harboring 37 and 44 gustducin-specific sequences at their C termini (G16/gust37 and G16/gust44) responded to different T2R receptors with known ligands, but G16/gust 23, G16/gust11, and G16/gust5 did not. The former two chimeras contained a predicted $\beta 6$ sheet, an $\alpha 5$ helix, and an extreme $\mathrm{C}$ terminus of gustducin, and all the domains were indispensable to the expression of T2R activity. We also expressed G16 protein chimeras with the corresponding domain from other $\mathrm{G} \alpha \mathrm{i}$ proteins, cone-transducin (G $\alpha \mathrm{t} 2)$, G $\alpha \mathrm{i} 2$, and $\mathrm{G} \alpha \mathrm{z}$ (G16/t2, G16/i2, and G16/z). As a result, G16/t2 and G16/i2 produced specific responses of T2Rs, but G16/z did not. Because $\mathrm{G} \alpha \mathrm{t} 2$ and $\mathrm{G} \alpha \mathrm{i} 2$ are expressed in the taste receptor cells, these G-protein $\alpha \mathrm{i}$ subunits may also be involved in bitter taste perception via T2R receptors. The present G $\alpha 16$-based chimeras could be useful tools to analyze the functions of many orphan G-protein-coupled taste receptors.
\end{abstract}

Key words: bitter taste; T2R receptor; G-protein $\alpha$ subunit; gustducin; $\mathrm{G} \alpha$ chimera; calcium imaging

\section{Introduction}

Taste perception is initially mediated by multiple signaling pathways in the taste receptor cells (TRCs) within taste buds in the oral epithelium. Bitter taste, as well as sweet taste, is believed to be detected by G-protein-coupled receptors (GPCRs), and the signaling pathways of TRCs have been the subject of intense speculation (for review, see Gilbertson et al., 2000; Lindemann, 2001; Margolskee, 2002; Montmayeur and Matsunami, 2002). $\alpha$-Gustducin is a transducin-like G $\alpha$ i protein selectively expressed in $20-30 \%$ of TRCs (McLaughlin et al., 1992). In vitro biochemical assays and in vivo physiological studies using knockout mice have demonstrated that gustducin plays a key role in TRC responses to numerous bitter compounds (Wong et al., 1996). However, gustducin knock-out mice still retained substantial sensitivity to bitter compounds in physiological and behavioral assays (Wong et al., 1996; He et al., 2002). In contrast, the second family of taste receptors identified, T2R (so-called TAS2R or TRB), is a large GPCR multigene family of $\sim 30 \mathrm{mem}-$ bers in humans and rodents (Adler et al., 2000; Matsunami et al., 2000). The genes map to regions of human and mouse chromosomes implicated genetically in sensitivity to various bitter compounds and are coexpressed with gustducin, suggesting that T2R receptors could function as gustducin-linked bitter taste recep-

Received May 6, 2003; revised June 9, 2003; accepted June 18, 2003.

This work was supported by research grants from the Japan Society for the Promotion of Science.

Correspondence should be addressed to Takashi Ueda, Department of Molecular Morphology, Graduate School of Medical Sciences, Nagoya City University, 1 Kawasumi, Mizuho-cho, Mizuho-ku, Nagoya 467-8601, Japan. E-mail: tueda@med.nagoya-cu.ac.jp.

Copyright $\odot 2003$ Society for Neuroscience $\quad$ 0270-6474/03/237376-05\$15.00/0 tors. Currently, there are two T2R receptors that display ligand responses with an affinity range compatible with behavioral sensitivity: mouse T2R5 (mT2R5) for cycloheximide (Chandrashekar et al., 2000) and human T2R16 (hT2R16) for salicin (Bufe et al., 2002). However, the other T2R receptors remain orphan receptors with no known ligands.

To measure T2R activity, previous studies used a heterologous expression system using human embryonic kidney 293/G $\alpha 15$ (HEK293/G $\alpha 15$ ) cells (Chandrashekar et al., 2000; Bufe et al., 2002). These cells stably express the $\alpha$ subunit of the mouse G-protein $\alpha$ subunit $(\mathrm{G} \alpha)$ protein $\mathrm{G} \alpha 15$, which is thought to indiscriminately couple to many GPCRs (Offermanns and Simon, 1995). In this strategy, transfection of G $\alpha 15$ into the cell system potentially allows measurements of elevated levels of intracellular calcium $\left[\mathrm{Ca}^{2+}\right]$ i, giving a simple readout for agonist activation, although there is evidence that bitter taste transduction is mediated by G $\alpha$ i-coupled receptors. However, G $\alpha 15$ cannot be considered as a true universal adapter for GPCRs, because $\sim 18 \%$ of the total number of G $\alpha$ i-coupled GPCRs examined to date cannot activate its human ortholog G $\alpha 16$ (Mody et al., 2000; Kostenis, 2001). Moreover, T2R receptors are believed to couple with gustducin in the native TRCs. In the present study, we constructed a variety of chimeric $\mathrm{G} \alpha$ proteins to determine the specific domain of gustducin necessary for T2R coupling and demonstrated that a specific domain of gustducin is indispensable to ligand responses compatible with behavioral sensitivity.

\section{Materials and Methods}

Materials. Animals were obtained from Shizuoka Laboratory Animal Center (Shizuoka, Japan). The human leukemic cell line, HL60, was 
obtained from the Japan Collection Research Bioresources Cell Bank (Japan). Reagents for reverse transcription PCR (RT-PCR) were obtained from Invitrogen (Carlsbad, CA) and Applied Biosystems (Branchburg, NJ). Cycloheximide was purchased from Biomol Research Laboratories (Plymouth Meeting, PA). Salicin, serum, culture media, and antiFLAG M2 and anti-opsin (Clone RET-P1) monoclonal antibodies were from Sigma (St. Louis, MO) unless otherwise noted.

Construction of $G \alpha$ proteins and chimeras. A variety of $\mathrm{G} \alpha$ subunits were obtained from a human cell line and rat tissues by RT-PCR. Human G $\alpha 16$ was obtained from HL60 cells. Rat $\alpha$-gustducin and G $\alpha$ i2 cDNAs were from rat lingual tissues containing circumvallate papillae. Similarly, rat $G \alpha t 2$ and $G \alpha z$ cDNAs were obtained from the retina and brain, respectively. All of the chimeras were constructed by PCRs using human $\mathrm{G} \alpha 16$ and rat-appropriated $\mathrm{G} \alpha$ cDNAs as templates. We first constructed a series of $\mathrm{G} \alpha 16$ /gustducin (G16/gust) chimeras by incorporating different lengths of gustducin amino acid sequences at the $\mathrm{C}$ terminus of G $\alpha 16$ : G16/gust44, G16/gust37, G16/gust23, G16/gust11, and G16/ gust5. In addition, we also constructed $\mathrm{G} \alpha 16$-based chimeras by replacing 44 amino acid sequences at the $\mathrm{C}$ terminus of $\mathrm{G} \alpha 16$ with those of $\mathrm{G} \alpha \mathrm{t} 2, \mathrm{G} \alpha \mathrm{z}$, or G $\alpha \mathrm{i} 2$ (G16/t2, G16/z, and G16/i2). All full-length $\alpha$-subunit cDNAs were subcloned into a pcDNA3.1(+) mammalian expression vector (Invitrogen). The G16/gust chimeras were also tagged by a FLAG epitope and cloned into the vector for expression assay and Western blot analysis.

Construction of T2R receptors. Mouse T2R 5 and human T2R16 were amplified from mouse and human genomic DNAs, respectively. We subcloned its open reading frame into pME18S-FL3 containing the first 39 amino acids of bovine rhodopsin in the frame. The sequences allow immunohistochemical detection and facilitate expression of the recombinant chemosensory receptors on the cell surface.

Transfection of HEK293T cells. HEK293T cells were cultured with DMEM and supplemented with $10 \% \mathrm{FCS}(\mathrm{v} / \mathrm{v})$ at $37^{\circ} \mathrm{C}$ in humidified air with $5 \% \mathrm{CO}_{2}$. For transfection, cells were seeded onto $100 \mathrm{~mm}$ dishes or uncoated glass coverslips in $35 \mathrm{~mm}$ chambers. After $24 \mathrm{hr}$ at $37^{\circ} \mathrm{C}$, cells were washed in DMEM medium and transfected with $\mathrm{G} \alpha$ and T2R using LipofectAmine 2000 reagent (Invitrogen). The transfection efficiencies were estimated by cotransfection of a GFP reporter plasmid or by immunohistochemistry and were typically $>70 \%$.

Western blot analysis. For Western blot analysis, a series of FLAGtagged G16/gust chimeras was used. Cells were grown on $100 \mathrm{~mm}$ dishes to $70-80 \%$ confluence. Transfection was performed on $35 \mathrm{~mm}$ dishes with proper adjustments for the volumes and amounts of the reagents used. After $36 \mathrm{hr}$ in normal growth conditions, cells were spun down briefly, resuspended in a lysis buffer $(20 \mathrm{~mm}$ Tri- $\mathrm{HCl}, \mathrm{pH}$ 7.4, 0.1\% SDS, $1 \%$ Triton X-100, $1 \%$ sodium decoxycholate) containing one protease inhibitor cocktail tablet (complete mini; Roche Products, Mannheim, Germany), lysed by one cycle of freeze-thawing followed by 10 passages through a 27 -gauge needle at $4^{\circ} \mathrm{C}$, and centrifuged at $15,000 \mathrm{rpm}$ for 30 min. Collected supernatants were used, and the protein concentrations were determined using a Bio-Rad (Hercules, CA) protein assay kit. Next, $50 \mu \mathrm{g}$ of each protein sample was resolved on a $10 \%$ SDS-polyacrylamide gel and transferred to Immobilon-P transfer membrane (Millipore, Bedford, MA) via electroblotting. FLAG-tagged $\mathrm{G} \alpha$ chimeras were detected by an anti-FLAG antibody followed by an alkaline phosphatase-labeled anti-mouse IgG secondary antibody and then visualized by a phosphatase reaction using nitro blue tetrazolium chloride and 5-bromo-4chlor-indolyl-phosphate (Roche Products).

Calcium imaging. We used a cell-based reporter system to examine T2R-G $\alpha$ interaction (Chandrashekar et al., 2000; Bufe et al., 2002). In this system, receptor activation leads to increases in intracellular calcium $\left[\mathrm{Ca}^{2+}\right] \mathrm{i}$, which can be monitored at the single-cell level using the fura-2 AM calcium indicator dye. HEK293T cells were transiently transfected with a rhodopsin-tagged T2R receptor with a G $\alpha 16$ - or G $\alpha 16$-based $\mathrm{G} \alpha$ chimera using LipofectAmine 2000 reagent. After 24-30 hr, transfected cells were loaded with $5 \mu \mathrm{M}$ fura-2 AM for $30 \mathrm{~min}$ at room temperature. The loading solution was washed out, and cells were incubated in $500 \mu \mathrm{l}$ of assay buffer (10 mM HEPES, $130 \mathrm{~mm} \mathrm{NaCl}, 10 \mathrm{~mm}$ glucose, $5 \mathrm{~mm} \mathrm{KCl}$, $2 \mathrm{mM} \mathrm{CaCl}_{2}$, and $1.2 \mathrm{mM} \mathrm{MgCl}_{2}, \mathrm{pH} 7.4$ ) and stimulated with tastants using a bath perfusion system at a flow rate of $5 \mathrm{ml} / \mathrm{min}$. We recorded

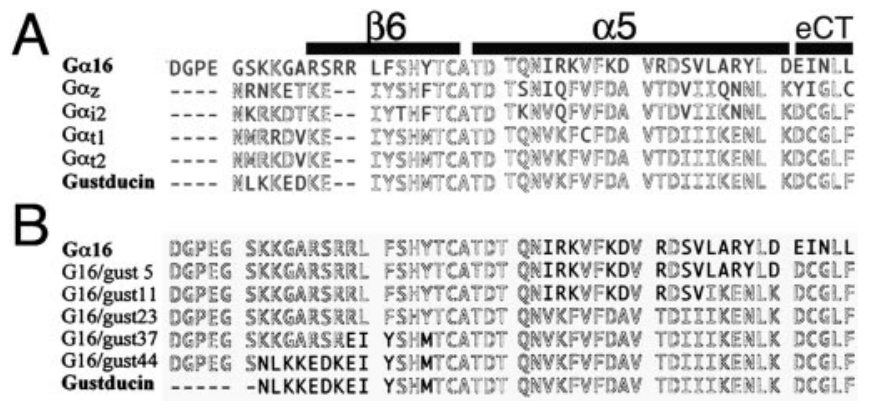

Figure 1. A, B, Alignments of C-terminal amino acid sequences of $\mathrm{G} \alpha 16, \mathrm{G} \alpha \mathrm{z}, \mathrm{G} \alpha \mathrm{i} 2, \mathrm{G} \alpha \mathrm{t} 1$, $\mathrm{G} \alpha \mathrm{t} 2$, and $\alpha$-gustducin $(A)$ and a variety of $\mathrm{G} 16 /$ gust chimeras ( $B$ ). Conserved sequences are in gray, and the sequences that differ from the majority are in black. Putative secondary structures on the basis of the $\mathrm{G} \alpha \mathrm{t} 1$ crystal structure are indicated by shaded bars above the $\mathrm{G} \alpha 16$ sequence in $A$. eCT, Extreme C terminus.

$\left[\mathrm{Ca}^{2+}\right]$ i changes using an Olympus IX-70 (Olympus Optical, Tokyo, Japan) equipped with the ARGUS-HiSCA system (Hamamatsu, Shizouka, Japan). Aquisition and analysis of the fluorescence images were done using ARGUS-HiSCA version 1.65 software. Generally, $\left[\mathrm{Ca}^{2+}\right]$ i response was measured by sequentially illuminating cells at 340 and $380 \mathrm{~nm}$ and monitoring the fluorescence emission at $510 \mathrm{~nm}$ using a cooled CCD camera. At the beginning of each experiment, $10 \mu \mathrm{M}$ isoproterenol was applied for $10 \mathrm{sec}$. A $180 \mathrm{sec}$ interval was then left between each tastant application to ensure that cells were not desensitized as a result of the previous application of tastants. In all cases, we measured the entire camera field. As a control, we used isoproterenol (10 $\mu \mathrm{M})$ to stimulate endogenous $\beta$-adrenergic receptors, proving that the G $\alpha 16$ dependent signal transduction cascade was functional. Approximately $70-80 \%$ of all cells in the camera field responded to isoproterenol, whereas $\sim 15-20 \%$ of all cells in the field showed dose-dependent responses to agonists in the transient transfection experiments. The proportion of responders was about half of that found by immunohistochemistry, which was similar to that in a previous study using $\mathrm{HEK} / \mathrm{G} \alpha 15$ cells (Bufe et al., 2002).

\section{Results}

Figure $1 A$ shows the alignment of the C-terminal amino acid sequences of the $\mathrm{G} \alpha$ used. Murine $\mathrm{G} \alpha 15$ has been successfully used to determine the function of two T2R receptors when stably expressed in HEK293 cells. Because its human ortholog, $\mathrm{G} \alpha 16$, is also known to interact with a wide variety of GPCRs, we first examined whether $\mathrm{G} \alpha 16$ could couple to T2R receptors in our transient expression system. Although we expressed G $\alpha 16$ with mT2R5, a cycloheximide receptor in the mouse, by transient transfection in HEK293T cells, the T2R receptor did not respond to the cycloheximide (Fig. 2). Similarly, hT2R16, which has been reported to react with a plant bitter tastant salicin, failed to respond to it (Fig. 2). In both cases, $10 \mu \mathrm{M}$ isoproterenol increased $\left[\mathrm{Ca}^{2+}\right] \mathrm{i}$ by activating an endogenous $\beta$-adrenergic receptor present in HEK293T cells. Untreated cells and cells without $\mathrm{G} \alpha 16$ did not respond to isoproterenol, indicating that human $\mathrm{G} \alpha 16$ could mediate intracellular calcium mobilization but could not couple to $\mathrm{T} 2 \mathrm{R}$ receptors in the present assay system. We thus used $\mathrm{G} \alpha 16$ as the basis of $\mathrm{G} \alpha$ chimeras for a functional assay on the basis of calcium imaging.

As numerous studies on $\mathrm{G} \alpha \mathrm{i}$ subunits have attested to the importance of the C-terminal tail of the $\alpha$ subunit as one of the major receptor contact regions, we constructed a series of $\mathrm{G} \alpha 16$ / gustducin chimeras by incorporating different lengths of gustducin sequences at the $\mathrm{C}$ terminus of $\mathrm{G} \alpha 16$ (Fig. $1 B$ ). First, because the $\alpha 5$ helix is a known contact region for receptors (Lichtarge et al., 1996), we replaced the entire $\alpha 5$ helix of G $\alpha 16$ with that of 

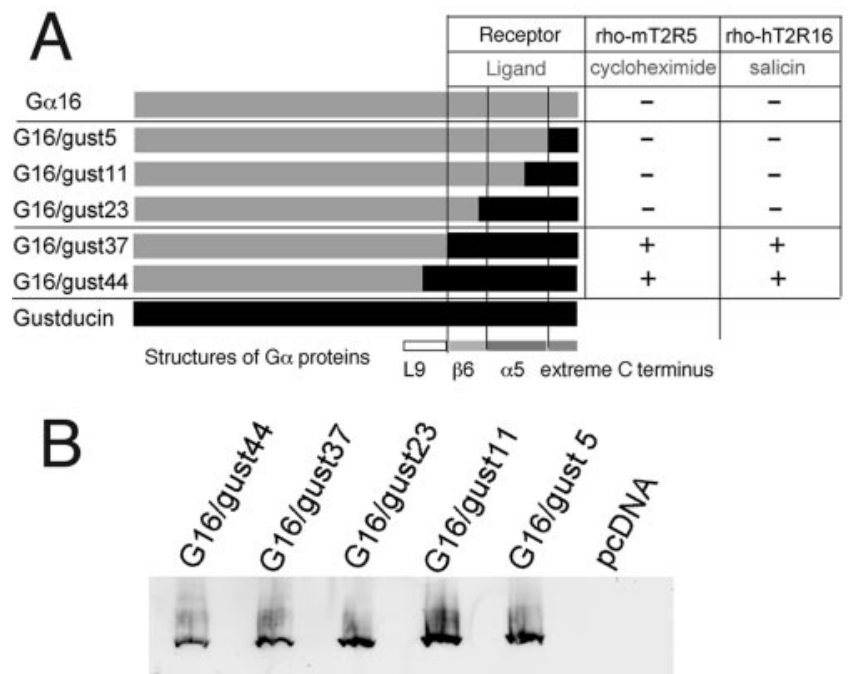

Figure 2. A, Schematic illustrations of chimeric $\mathrm{G} 16 /$ gust proteins with different lengths of $\mathrm{C}$ terminal amino acids found in gustducin and their abilities to couple to T2Rs. +, Specifically responded to the ligand in dose-dependent manner; - , did not exhibit any responses. $B$, Immunoblot analysis of FLAG-tagged chimeric G16/gust subunits expressed in HEK293T cells, stained with the anti-FLAG M2 monoclonal antibody. The FLAG epitope tag did not influence the functional activity of $\mathrm{G} 16 /$ gust chimeras.

gustducin. The resultant chimera was named G16/gust23; for G16/gust23 and subsequent chimeras, the number after the latter gust indicates the number of gustducin residues present in the $\mathrm{C}$ terminus of the construct. Second, another region determining coupling selectivity is the extreme $\mathrm{C}$ terminus (also called C-terminal turn or $\beta$-turn) (Conklin et al., 1993; Blahos et al., 2001). G16/gust 5 contains the minimum sequences of gustducin that correspond to the region decisive for coupling of $\mathrm{G} \alpha$ proteins with specific receptors. G16/gust11 was designed from a $\mathrm{G} \alpha$ $\mathrm{COOH}$-terminal minigene vector to explore the coupling mechanisms of receptors (Gilchrist et al., 2002). Last, the region between $\alpha 4$ and $\alpha 5$ helices that includes the L9 loop and $\beta 6$ sheet is also involved in coupling selectivity, probably by directly interacting with the receptors of the rhodopsin-like family (family 1 GPCRs) (Noel et al., 1993). G16/gust44 contains all the structures, an L9 loop, a $\beta 6$ sheet, an $\alpha 5$ helix, and an extreme C terminus of gustducin, whereas G16/gust37 includes the latter three structures. We also made FLAG epitope-tagged G16/gust chimeras, but the results obtained using these epitope-tagged chimeras were identical to those using the $\mathrm{G} \alpha$ chimeras without epitope tags.

We used a well established transient expression system to examine the ability of the G16/gust chimeras to interact with T2R receptors (see Materials and Methods). We first examined the response against cycloheximide in HEK293T cells coexpressing the rhodopsin-mT2R5 (rho-mT2R5) with G16/gust44, G16/ gust37, G16/gust23, G16/gust11, or G16/gust5. When transfected with T2R and either G16/gust44 or G16/gust37, cells specifically responded to cycloheximide (Figs. 2 and 3). The response was receptor- and $\mathrm{G} \alpha$ chimera-dependent, because cells lacking either of these components did not cause a $[\mathrm{Ca} 2+] \mathrm{i}$ increase, even at a 1000 -fold higher cycloheximide concentration. In this assay, the $\mathrm{EC}_{50}$ value of $\mathrm{mT} 2 \mathrm{R} 5$ was $0.5 \mu \mathrm{M}$, and the threshold was $\sim 0.2$ $\mu \mathrm{M}$ (Fig. 3). These responses resembled those obtained from behavioral experiments with rodents (sensitivity threshold, $\sim 0.25$ $\mu \mathrm{M}$ ), indicating that G16/gust 44 and G16/gust 37 can functionally couple to mT2R5. In contrast, the other G-protein chimeras
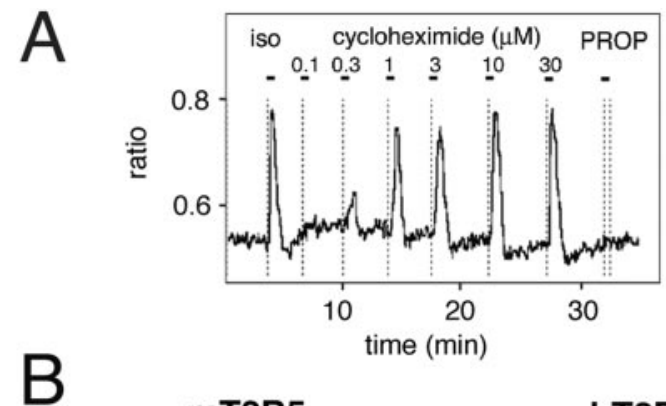

\section{mT2R5}

\section{hT2R16}
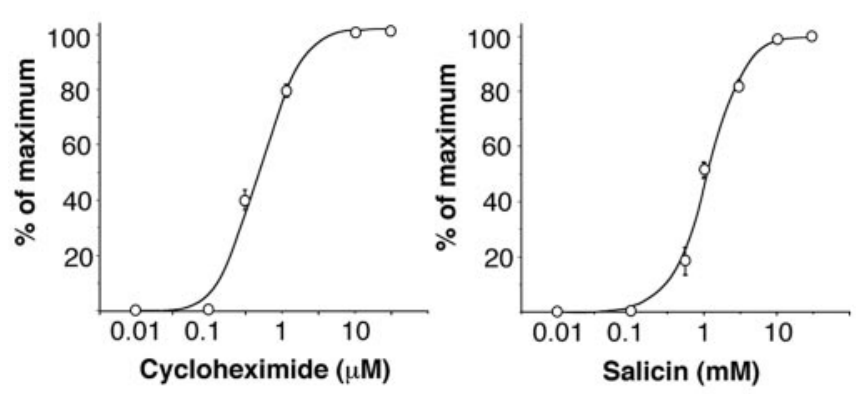

Figure 3. $\quad A_{1}\left[\mathrm{Ca}^{2+}\right]$ i responses in HEK293T cells expressing G16/gust37 and rho-mT2R5 when treated with multiple pulses of $10 \mu \mathrm{m}$ isoproterenol (iso), cycloheximide, and $3 \mathrm{~mm}$ PROP (6-n-propylthiouracil). Isoproterenol was used to ascertain that the G16-dependent signaling cascade was functional. Horizontal bars above the traces indicate the time and duration of tastant pulses. Cycloheximide triggered robust receptor activation, but PROP did not. Similar results were obtained when $\mathrm{G} 16 /$ gust 44 was used in place of $\mathrm{G} 16 /$ gust 37 . B, Dose-dependent curves of the effects of the ligands on the $\left[\mathrm{Ca}^{2+}\right] \mathrm{i}$ in cells expressing $\mathrm{G} 16 /$ gust 37 and the T2R receptor indicated.

(G16/gust23, G16/gust11, and G16/gust5) failed to mediate the cycloheximide response under identical experimental conditions (Fig. 2). These G16/gust chimeras did not mediate any responses, even at 1000-fold higher ligand concentration. Hence, we checked the expression of the G16 chimeras by Western blot analysis using an anti-FLAG M2 monoclonal antibody for the immunodetection. As shown Figure 2, all chimeras were detected by the antibody in proteins prepared from HEK293T transfected with the FLAG-tagged chimeras. There were no differences in protein expression between them (Fig. 2).

The ability of G16/gust44 and G16/gust37 to interact productively with the mT2R 5 receptor prompted us to further investigate their capacity to functionally associate with another T2R receptor. HEK293T cells were cotransfected with either G16/ gust44 or G16/gust37 and rho-hT2R16. In transfected cells, stimulation of the ligand for hT2R16 (salicin) significantly increased $\left[\mathrm{Ca}^{2+}\right]$ i (Fig. 2). Such $\left[\mathrm{Ca}^{2+}\right] \mathrm{i}$ increases were receptor- and $\mathrm{G} \alpha$ chimera-dependent and were in a dose-dependent manner. The $\mathrm{EC}_{50}$ and threshold were $\sim 2$ and $0.2 \mathrm{~mm}$, respectively (Fig. 3). These closely resembled those obtained in experiments with human subjects reported previously (Bufe et al., 2002). Thus, G16/ gust44 and G16/gust37 successfully interacted with hT2R16 in addition to mT2R5. However, the other chimeras (G16/gust23, G16/gust11, and G16/gust5) did not mediate any ligand responses via hT2R16. Thus, the $\mathrm{C}$-terminal 37 amino acid residues containing the predicted $\beta 6$ sheet, $\alpha 5$ helix, and extreme $\mathrm{C}$ terminus of gustducin may be necessary for productive functional expression of $\mathrm{T} 2 \mathrm{R}$ taste receptors.

It has been suggested that in native mammalian TRCs, bitter taste may also be mediated by $\mathrm{G} \alpha$ proteins other than gustducin. We tested whether the T2Rs studied could associate with the 


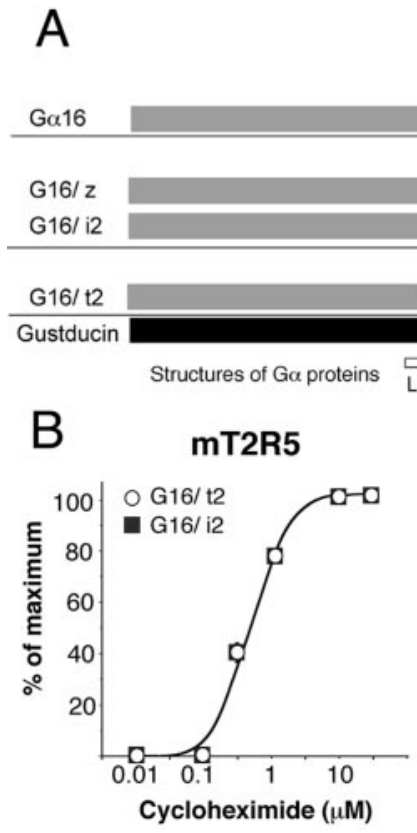

\begin{tabular}{|c|c|c|}
\hline Receptor & rho-mT2R5 & rho-hT2R16 \\
\hline Ligand & cycloheximide & salicin \\
\hline & - & - \\
\hline & - & - \\
\hline & + & + \\
\hline & + & + \\
\hline
\end{tabular}

L9 $\quad \beta 6 \quad \alpha 5$ extreme C terminus

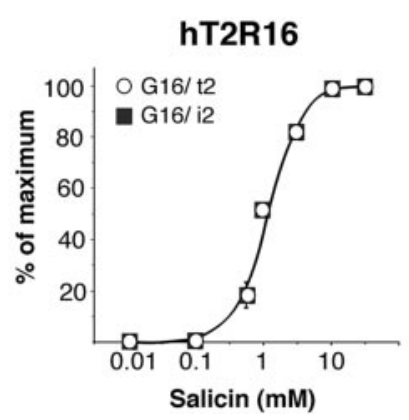

Figure 4. A, Schematic illustrations of chimeric G16 proteins with 44 C terminal amino acids of different $G \alpha$ proteins and their ability to couple to T2Rs. + , Specifically responded to the ligand in a dose-dependent manner; - , did not exhibit any responses. B, Dose-dependent curves of the effects of ligands on the $\left[\mathrm{Ca}^{2+}\right] \mathrm{i}$ in cells expressing $\mathrm{G} 16 / \mathrm{t} 2$ or G16/i2 and the T2R receptor indicated.

C-terminal domain of other $\mathrm{G} \alpha$ proteins corresponding to the $\beta 6$ sheet, $\alpha 5$ helix, and extreme $\mathrm{C}$ terminus of gustducin. We constructed $\mathrm{G} \alpha 16$ chimeras with 44 amino acid $\mathrm{C}$ termini found in a variety of $\mathrm{G} \alpha \mathrm{i}$ proteins, including $\mathrm{G} \alpha \mathrm{t} 2, \mathrm{G} \alpha \mathrm{i} 2$, and $\mathrm{G} \alpha \mathrm{z}$ (Fig. 1A) (G16/t2, G16/i2 and G16/z), and assayed them under identical experimental conditions to the experiments of G16/gust chimeras. As a result, G16/t2 and G16/i2 exhibited effective couplings with both mT2R5 and hT2R16 whereas G16/z did not (Fig. 4A). The dose-dependent curves were similar to those obtained from G16/gust chimeras that coupled to these receptors (Fig. 4B). There are no significant differences in the potency and efficacy between G16/t2 and G16/i2.

\section{Discussion}

To determine essential domains for coupling to GPCR, many loss-of-function-type mutation studies on G-proteins have been done. However, mutations of structurally important G-protein domains can also inhibit functional coupling with GPCRs, although the mutation domains themselves are not binding sites for GPCRs. In the present study, we constructed a variety of chimeric $\mathrm{G} \alpha$ proteins to better understand the domains involved in the interactions between T2R and gustducin. In addition, these chimeric $\mathrm{G} \alpha$ proteins enabled us to analyze gustducin-linked GPCRs on common robust assays that are amenable to high throughput-screening analysis. We monitored $\left[\mathrm{Ca}^{2+}\right] \mathrm{i}$ increases caused by activation of signaling cascade T2R-heterotrimeric G-protein $(\mathrm{G} \alpha \beta \gamma)$-phospholipase C-inositol 3,4,5 triphosphate receptor. From the $\mathrm{G}$-protein $\alpha, \beta$, and $\gamma$ subunits, probably both $\mathrm{G} \alpha$ and $\beta \gamma$ dimers contact the receptors. The $\mathrm{G} \alpha$ subunit is likely to play a decisive role in discriminating between different receptor subtypes (Savarese and Fraser, 1992; Bourne, 1997; Wess, 1997). Here, we demonstrated that G16/gust 44 and G16/gust 37 successfully coupled to T2R receptors for their signal transduction. These responses were comparable with those obtained from in vivo experiments, and there is evidence that mT2R 5 can activate intact gustducin in vitro (Chandrashekar et al., 2000), indicating that our system is capable of reproducing signaling transduction of T2R receptors in native TRCs. In contrast, G16/gust23 that contained the $\alpha 5$ helix of gustducin appeared not to associate, although numerous studies have attested to the importance of the $\alpha 5$ helix in receptor coupling. Similarly, G16/gust11 and G16/gust5 did not cause T2R activity. These results indicated that the $\alpha 5$ helix and extreme $\mathrm{C}$ terminus of gustducin were insufficient for detection of T2R activities, and the $\beta 6$ sheet, in addition to the $\alpha 5$ and $\mathrm{C}$-terminal $\beta$-sheet, is indispensable for signal transduction of T2Rs.

We next tested whether T2Rs could couple to domains including the $\beta 6$ sheet, $\alpha 5$, and extreme $\mathrm{C}$ terminus from other G-protein $\alpha$ subunits. As a result, we revealed that some G16 chimeras constructed from other G $\alpha$ proteins, G16/t2 and G16/ $\mathrm{i} 2$, functionally coupled with the T2R receptors examined. Rod$\alpha$-transducin $(\mathrm{G} \alpha \mathrm{t} 1)$ and cone- $\alpha$-transducin $(\mathrm{G} \alpha \mathrm{t} 2)$ are present in vertebrate taste cells. The former has been reported to transduce bitter taste by coupling taste receptor(s) to taste cell phosphodiesterase (Ruiz-Avila et al., 1995). In addition, gustducin and rod-transducin are biochemically indistinguishable in their in vitro interactions with retinal phosphodiesterase, rhodopsin (retinal GPCR), and G-portion $\beta \gamma$ subunits (Hoon et al., 1995). Because the amino acid sequences of the $\beta 6$ sheet and $\alpha 5$ helix in $\mathrm{G} \alpha \mathrm{t} 1$ and $\mathrm{G} \alpha \mathrm{t} 2$ are almost identical to those of gustducin (Fig. $1 A)$, the $\mathrm{C}$-terminal region $(\beta 6, \alpha 5$, and extreme $\mathrm{C}$ terminus) conserved could be one of the most important domains for $\alpha$-gustducin, G $\alpha \mathrm{t} 1$, and G $\alpha \mathrm{t} 2$ to interact with GPCRs.

In the present study, functional expression of T2R receptors was also observed in HEK293T cells coexpressing G16/i2 and T2R receptors, suggesting that T2Rs cannot only couple to gustducin and transducin but also to the G-protein $\alpha \mathrm{i} 2$ subunit. One or more G-protein $\alpha$ subunits may play a role in bitter taste transduction, because $\alpha$-gustducin knock-out mice retain residual responsiveness to bitter compound. In addition, transgenic expression of a dominant-negative form of $\alpha$-gustducin from the gustducin promoter further decreased the residual responses of $\alpha$-gustducin knock-out mice apparently by inhibiting T2R/TRB interactions with other TRC-expressed G-protein $\alpha$ subunits (Margolskee, 2002). It has been reported that Goi2 subunit is expressed in subsets of TRCs. The frequency of G $\alpha \mathrm{i} 2$ expression

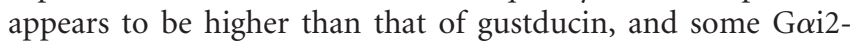
positive cells also express $\alpha$-gustducin (Kusakabe et al., 2000). Goi2 could thus function as "backup" for gustducin in T2Rgustducin-expressing TRCs. In contrast, several TRCs that are immunoreactive for $\mathrm{G} \alpha \mathrm{i} 2$ but not for gustducin responded to cycloheximide in an in vivo recording using mouse lingual slices (Caicedo et al., 2002). This suggests that G $\alpha \mathrm{i} 2$ may be involved in gustducin-independent bitter taste transduction via other G-protein-coupled receptors as well as T2Rs. On the basis of in situ hybridization with a mix of 10 different T2R probes, it was concluded that T2R genes are selectively expressed in gustducinexpressing taste receptor cells (Adler et al., 2000). However, a recent genomic study has shown that mouse T2R (Tas 2 r) family is composed of at least 36 full-length genes (Shi et al., 2003). Additional studies are required to determine whether all of the $\mathrm{T} 2 \mathrm{R}$ genes are exclusively expressed in gustducin-expressing cells.

Many G $\alpha$ i-coupled GPCRs share the ability to inhibit adenylyl cyclase via the pertussis toxin-insensitive $\mathrm{G} \alpha \mathrm{z}$ (Chan et al., 1995; Lai et al., 1995). The incorporation of a G $\alpha z$-specific sequence into a $\mathrm{G} \alpha 16$ backbone $(\mathrm{G} 16 / \mathrm{z})$ successfully improved the recog- 
nition of a variety of G $\alpha$ i-coupled receptors (Mody et al., 2000). However, the G16/z chimera was incapable of responding to the T2Rs studied in the present experiments, indicating that T2R receptors have specific sequences for interacting with gustducin and G $\alpha$ i2. Within the $\beta 6$ sheet and $\alpha 5$ helix ( 37 amino acids), there are five amino acids that are conserved in gustducin and Goi2 but not in Goz: V333, K346, D350, C351, and F354 in gustducin (at position $-23,-10,-5,-4$, and -1 , respectively; the residues -1 being the last one) (Fig. $1 A$ ). In particular, the latter three amino acids are contained in the extreme $\mathrm{C}$ terminus of the $\mathrm{G} \alpha$ protein. Indeed, a gustducin mutant containing a glycine-to-proline substitution at position -3 can bind to taste receptor $\mathrm{G} \beta \gamma$ subunits and the effector, but it cannot be activated by receptors (Ruiz-Avila et al., 2001). Therefore, the extreme C terminus may also play an important role in transduction via the gustducin, $\mathrm{G} \alpha \mathrm{t} 1, \mathrm{G} \alpha \mathrm{t} 2$, and $\mathrm{G} \alpha \mathrm{i} 2$ of T2R taste receptors.

In conclusion, we found that $37 \mathrm{C}$ terminal amino acids $(\beta 6$, $\alpha 5$, and extreme $\mathrm{C}$ terminus) of gustducin and $\mathrm{G} \alpha \mathrm{i} 2$ are indispensable for the detection of T2R activity. Because T2Rs have the greatest conservation in their cytoplasmic loops and adjacent transmembrane segments, which are the predicted sites for G-protein interaction, the present chimeric G16/gust proteins could be powerful tools to analyze orphan gustducin-linked taste receptors.

\section{References}

Adler E, Hoon MA, Mueller KL, Chandrashekar J, Ryba NJP, Zucker CS (2000) A novel family of mammalian taste receptors. Cell 100:693-702.

Blahos J, Fischer T, Brabet I, Stauffer D, Rovelli G, Bockaert J, Pin J-P (2001) A novel site on the $\mathrm{G} \alpha$-protein that recognizes heptahelical receptors. J Biol Chem 276:3262-3269.

Bourne HR (1997) How receptors talk to trimeric G-proteins. Curr Opin Cell Biol 9:134-142.

Bufe B, Hofmann T, Krautwurst D, Raguse J-D, Meyerhof W (2002) The human TAS2R16 receptor mediates bitter taste in response to $\beta$-glucopyranosides. Nat Genet 32:397-401.

Caicedo A, Pereira E, Margolskee RF, Roper SD (2002) G $\alpha$-proteins involved in bitter taste detection. Poster presented at the 32nd Annual Meeting of the Society for Neuroscience, Orlando, FL, November.

Chan JSC, Chiu TT, Wong YH (1995) Activation of type II adenylyl cyclase by the cloned $\mu$-opioid receptor: coupling to multiple G-proteins. J Neurochem 65:2682-2689.

Chandrashekar J, Mueller KL, Hoon MA, Adler E, Feng L, Guo W, Zucker CS, Ryba NJP (2000) T2Rs function as bitter taste receptors. Cell 100:703-711.

Conklin BR, Farfel Z, Lustig KD, Julius D, Bourne HR (1993) Substitution of three amino acids switches receptor specificity of $\mathrm{Gq} \alpha$ to that of $\mathrm{Gi} \alpha$. Nature 363:274-276.

Gilbertson TA, Damark S, Margolskee RF (2000) The molecular physiology of taste transduction. Curr Opin Neurobiol 10:519-527.
Gilchrist A, Li A, Hamm HE (2002) G $\alpha$ COOH-terminal minigene vectors dissect heterotrimeric G-protein signaling. Sci STKE 2002:PL1.

He W, Danilova V, Zou S, Hellekant G, Max M, Morgolskee RF, Damak S (2002) Partial rescue of taste responses of $\alpha$-gustducin null mice by transgenic expression of $\alpha$-transducin. Chem Senses 27:719-727.

Hoon MA, Northup JK, Margolskee RF, Ryba NJP (1995) Functional expresssion of the taste specific G-protein, $\alpha$-gustducin. Biochem J 309:629-636.

Kostenis E (2001) Is G $\alpha 16$ the optimal tool for fishing ligands of orphan G-protein-coupled receptors? Trends Pharmacol Sci 22:560-564.

Kusakabe Y, Yasuoka A, Asano-Miyoshi M, Iwabuchi K, Matsumoto I, Arai S, Emori Y, Abe K (2000) Comprehensive study on G-protein $\alpha$-subunits in taste bud cells, with special reference to the occurrence of $\mathrm{G} \alpha \mathrm{i} 2$ as a major $\mathrm{G} \alpha$ species. Chem Senses 25:525-531.

Lai HWL, Minami M, Satoh M, Wong YH (1995) Gz coupling to the rat $\kappa$-opioid receptors. FEBS Lett 360:97-99.

Lichtarge O, Bourne HR, Cohen FE (1996) Evolutionarily conserved Galphabetagamma binding surfaces support a model of the G-proteinreceptor complex. Proc Natl Acad Sci USA 93:7507-7511.

Lindemann B (2001) Receptors and transduction in taste. Nature 413:219-225

Margolskee RF (2002) Molecular mechanisms of bitter and sweet taste transduction. J Biol Chem 277:1-4.

Matsunami H, Montmayeur J-P, Buck LB (2000) A family of candidate taste receptors in human and mouse. Nature 404:601-603.

McLaughlin SK, McKinnon PJ, Margolskee RF (1992) Gustducin is a tastecell-specific G-protein closely related to transducins. Nature 357:563-569.

Mody SM, Ho MKC, Joshi SA, Wong YH (2000) Incorporation of G $\alpha$ specific sequence at the carboxyl terminus increases the promiscuity of Ga16 toward Gi-coupled receptors. Mol Pharmacol 57:13-23.

Montmayeur J-P, Matsunami H (2002) Receptors for bitter and sweet taste. Curr Opin Neurobiol 12:366-371.

Noel JP, Hamm HE, Sigler PB (1993) The 2.2 A crystal structure of transducin-alpha complexed with GTP gamma S. Nature 366:654-663.

Offermanns S, Simon MI (1995) G $\alpha 15$ and G $\alpha 16$ couple a wide variety of receptors to phospholipase C. J Biol Chem 270:15175-15180.

Ruiz-Avila L, McLaughlin SK, Wildman D, McKinnon PJ, Robichon A, Spickofsky N, Margolskee RF (1995) Coupling of bitter receptor to phosphodiesterase through transducin in taste receptor cells. Nature 376: $80-85$.

Ruiz-Avila L, Wong GT, Damak S, Margolskee RF (2001) Dominant loss of responsiveness to sweet and bitter compounds caused by a single mutation in $\alpha$-gustducin. Proc Natl Acad Sci USA 98:8868-8873.

Savarese TM, Fraser CM (1992) In vitro mutagenesis and the search for structure-function relationships among G-protein-coupled receptors. Biochem J 283:1-19.

Shi P, Zhang J, Yang H, Zhang Y (2003) Adaptive diversification of bitter taste receptor genes in mammalian evolution. Mol Biol Evol 20:805-814.

Wess J (1997) G-protein-coupled receptors: molecular mechanisms involved in receptor activation and selectivity of G-protein recognition. FASEB J 11:346-354.

Wong GT, Gannon KS, Margolskee RF (1996) Transduction of bitter and sweet taste by gustducin. Nature 381:796-800. 